\title{
PARAMETRIZATION OF TYPICAL WORD-FORMATION PARADIGMS OF THE ADJECTIVAL VERBS IN THE UKRAINIAN LANGUAGE DENOTING PROCESS AND ACTION
}

Kushlyk O. P.

\section{INTRODUCTION}

One of important stages in the study of word formation is the analysis of the derivational potential of words with the emphasis on a formation basis (stem) as a typology factor and as a means of derivatives systematization, interpretation of their structure, semantics and functioning. The orientation based on this approach is reflected by the term "stem-centered". In theoretical derivatology, the shift of attention in wordformation processes from the word-building affix (formant) to the stem is conditioned by the general tendency towards the development of the stemcentered direction. The significance of this approach is evident and it was often pointed to by Professor Ivan Kovalyk, a well-known Slavic scholar, derivatologist and the founder of the Ukrainian word formation. He was convinced that such an aspect of studying the system of word-formation of this language would help to understand better the word-formation facts and would give more reliable grounds for making deeper conclusions and generalizations on the theoretical issues of the study of word formation ${ }^{1}$.

The general-categorial meaning of the stem, its structure, semantics and functional load influences on the word-building ability of different lexico-grammatical parts and within them lexico-semantic groups. As a result such influence gives opportunity to trace the relationship between the meaningful structures of the base and derivative units, to predict the formation of derivatives with a certain word-formation meaning, to establish inventory of word-formation means for its explication, to find out the reasons for non-implementation of the derivation ability of the stems in some semantic positions, to reflect the dynamics of the word-formation process.

With the development of the stem-centered approach in the derivational study, the linguists are facing the problem of the introduction of a special complex unit of classification and description of wordformation material that would be adequate to the key principles. The word-

\footnotetext{
${ }^{1}$ Ковалик I. І. Словотвір іменників у сербо-лужицьких мовах. Львів, 1964. С. 44-45.
} 
building paradigm as a set of derivatives formed from one stem at one derivation level becomes such a unit. It is known, however, that some linguists, the Ukrainian linguists in particular, tried to systematize and describe the material by means of a word-formation nest as a typologizing factor in the stem-centered aspect. It was stated in the numerous researches which supported this word-forming principle ${ }^{2}$. The authors of these academic works argued that the word-building nest makes it possible to find out the word-formation activity and generative ability of the basic word; to reveal the structure of the word-building nest; to analyze the correlation of derivative units of different part-of-speech belonging, their number, degree of word formation; to identify an array of word-building means; to establish a hierarchy of relations between the members of the nest, semantic relations between common-root words, types of motivation of a basic word, ways of organizing the internal structure of derivative words, modification of the semantics of a basic word in the semantics of a derivative word ${ }^{3}$. However, according to V. Greshchuk, who worked out the mechanisms of the word-paradigmatic principle of systematization of the material, the word-building paradigm is a more "optimal and operable complex unit of classification and description than a word-building nest" as it fixes the first steps of the nest, which are repeated in other basic words contributing to its typologization.

\section{The review of literature}

There has already been extensive research in the Slavic linguistic tradition on the definition of the word-building potential of words of different part of speech on the basis of the word-paradigmatic principle of systematization of the material. Most of them are studios which establish the derivational potential of verbs as one of the central parts of speech with the most extensive system of grammatical categories. The following well-known derivatologists have made their contribution into the development of the stem-centered theory in the field of verb semantics: in the Slovak language Klara Buzášsyová; in Polish - Renata Grzegorczykowa, Hanna Jadacka;

\footnotetext{
2 Голянич М. И. Словообразовательные поля корней со значением говорения в современном украинском языке : автореф. дисс. ... канд. филол. наук : 10.02.02. Киев, 1979. 24 с.; Лесюк Н. П. Словообразовательные гнёзда корней со значением движения в современном украинском языке : автореф. дисс. ... канд. филол. наук : 10.02.02. Киев, 1982. 25 с.; Василевич Г. Я. Типи словотвірних значень девербативів-іменників у віддієслівних гніздах зі значенням мислення. Дослідження зі словотвору та лексикології. Київ : Вища школа, 1985. С. 25-30.

3 Лесюк М. П. Дослідження словотвору на рівні словотвірних гнізд. Вісник Прикарпатського нац. ун-ту ім. В. Стефаника. Філологія. Івано-Франківськ: Вид-во Прикарпатського нац. ун-ту, 2007. Вип. 15-18. С. 213.

4 Ірещук В. В. Теоретичні засади основоцентричної дериватології. Відприкметниковий словотвір / В. В. Грещук, Р. О. Бачкур, І. Ф. Джочка, Н. М. Пославська. Нариси з основоцентричної дериватології. Івано-Франківськ : Місто НВ, 2007. С. 24.
} 
in Russian - Yelena Zemskaya, Tatyana Morozova; in Bulgarian Stefana Kaldieva-Zakharieva, Elena Georgieva, Vera Nechaeva.

The Ukrainian stem-centered derivatology began to develop somewhat later. Although, it has significant achievements nowadays thanks to V. Greshchuk's elaborated word-paradigmatic principles, which formed the basis for describing the derivational potential of the adjectival system $^{5}$. Derivational potencies of the verbs draw much attention in the Ukrainian derivatology. The scholars work in the two directions. One of them is to study word-building capabilities of words belonging to different lexico-semantic groups. In particular, Iryna Dzhochka and Nataliia Poslavska have analyzed the verbs with the meaning of specific physical action $^{6}$; Lubomyr Segin focused on the verbs denoting dynamic spatial localization $^{7}$ and Nadiia Adamets studied the verbs of motion ${ }^{8}$. Others scholars establish a word-building paradigmatics of the words of different parts of speech. In this case a word`s origin (primary or secondary) plays a very important role. For example, Oksana Kushlyk has determined the word-building potential of the secondary verbs, specifically the verbs of a noun, adjectival and ontomatopoic origin?

By typologizing this or that material, scholars bring up the issue of the factors which activize word-formation behavior. Ukrainian derivatologists single out such factors as: the origin of topmost verbs (primary or secondary), for secondary verbs - the motivation by a word of a certain part of speech; belonging of verbatives as the topmost of the word-building paradigms to a definite lexico-semantic group or structural-semantic type. Later this complex of factors predicts the development of certain syntagmatic relations between this verb and other words and the corresponding categorical status of the analyzed verbs in the sentence action, state or process, with the word-formation potencies of which varying considerably among themselves ${ }^{10}$. The categorical status of verbs is undoubtedly an important indicator of their word-building ability, as it enables to find out their semantic capacity and their semantic structure, to

\footnotetext{
${ }^{5}$ Грещук В. Український відприкметниковий словотвір. Івано-Франківськ : Плай, 1995. 208 с.

6 Джочка І. Ф., Пославська Н. М. Віддієслівний словотвір // В. В. Грещук, Р. О. Бачкур та ін. Нариси з основоцентричної дериватології. Івано-Франківськ : Місто НВ, 2007. С. 154-324;

7 Сегін Л. В. Структурно-семантична типологія словотвірних парадигм дієслів динамічної просторової локалізованості в українській та польській мовах : автореф. дис. ... канд. філол. наук : 10.02.17. Донецьк, 2003. 20 с.

${ }^{8}$ Адамець Н. В. Словотвірна парадигматика дієслів руху в сучасній українській мові : автореф. дис. ... канд. філол. наук : 10.02.01. Івано-Франківськ, 2016. 20 с.

9 Кушлик О. П. Словотвірна парадигматика похідних дієслів в українській мові : монографія. Дрогобич : Коло, 2015. 384 с.

10 Кушлик О. П. Словотвірна парадигматика похідних дієслів в українській мові : монографія. Дрогобич: Коло, 2015. С. 293-294; Соколов О. М. До проблеми зв'язку словотвірної мотивації з валентністю мовних одиниць. Проблеми сучасного життя мови. Київ, Наукова думка, 1977. С. 3.
} 
establish the "potential of their semantic valency", to identify codified derivatives of a word-building paradigm with the definition of the continuum of realized semantic positions and to predict possible formations. This will be explained on the material of the adjectival verbs of the Ukrainian language. Their belonging to three different structural-semantic types (inchoatives, essives or causatives) determines their functionalcategorical status - action, process or state - in a definite context. This fact, in its turn, affects the derivative ability of the topmost verb.

The purpose of the proposed article is to establish the typology of word-building paradigms of Ukrainian verbs motivated by adjectives for denoting the features and qualities of objects, which are perceived by our sense organs, paying attention to the functional-categorical status of the topmost verbs.

\section{Methodology}

The inventorization of the material is carried out according to the principle of paradigm-formation which involves singling out concrete and typical word-building paradigms.

The concrete word-building paradigm fixes the whole set of derivatives of the first level of formation. The common element in their meaning and the meaning of the topmost word is a relevant feature, on the basis of which the structural-semantic peculiarities of the derivatives are determined as well as their constant, word-formation meanings defined in the paradigm. In addition, the need to single out a concrete word-building paradigm is conditioned by the peculiarity of the verbs of the definite word-building type determined by the common word-formation meaning, a derivational affix and a stem (noun, adjectival or onomatopoeic) to produce a different number of deverbatives.

The filling of a concrete word-building paradigm depending of the part of speech the derivatives belong to is structured by morphological zones as indicators of the length of the word-building paradigm. The sequence of locations of these zones is different. Some researchers keep to the sequence analysis for the parts of speech generally accepted in grammar, namely: the nominal parts (nouns, adjectives) followed by verbs. Accordingly, within the word-building paradigm there are substantive, adjectival and verbal zones. Others place the derivatives of the adjectival zone after the derivatives of the verbal zone due to their limited number. Generative ability of derivative verbs determines their word-building formant: derivatives of the substantive and adjectival zones are mostly suffixal derivative units; in contrast, the

\footnotetext{
${ }^{11}$ Уфимцева А. А. Лексическое значение. Москва : Наука, 1986. С. 72.
} 
derivatives of the verbal zone are created by suffixal, prefixal, prefixalsuffixal, prefixal-postfixal and postfixal ways of formation.

The explication of one word-formation meaning with the help of several word-building means testifies to the depth of the semantic position which is, at the same time, the depth of a concrete word-building paradigm - its second parametric characteristic. The components of a concrete word-building paradigm are in the relation of the derivativeness with the topmost word and among themselves - in the relation of coderivation, i. e. semantic equality.

A typical word-forming paradigm is formed by concrete paradigms in which the same set of derivational meanings is available ${ }^{12}$. However, the set of realized word-formation meanings, respectively, the composition of the typical and concrete word-building paradigms of a verb of the same word-building type do not often coincide, which is caused by the basic principle of generalization of the actual material. In addition, the depth of a concrete word-building paradigm does not belong to the characteristic features of a typical word-formation paradigm as it does not change the total number of distinguished semantic positions.

\section{Results and discussion}

Adjectival verbs are verbs semantically motivated and structuralized by adjectives. There are different views on the semantic and functional peculiarities of the adjectival verbs in linguistics which have led to various structural-semantic classifications. Scholars distinguish three main structural-semantic types: 1) inchoatives, i. e. verbs with word-formation meaning "to acquire a feature and quality named by the basic adjective"; 2) essives, i. e. verbs with word-formation meaning "to reveal a feature and quality named by the basic adjective"; 3 ) causatives, i. e. the verbs with the word-building meaning "to endow an object with a feature and quality named by the basic adjective" ${ }^{\prime 3}$. In contrast to such an approach, V. Greshchuk classified them into two types: 1) verbs with word-formation meaning "to endow an object with a feature and quality"; 2) verbs with the word-formation meaning "to acquire a feature and quality"14. However, he

\footnotetext{
12 Земская Е. А. О парадигматических отношениях в словообразовании. Русский язык : Boпросы его истории и современного состояния. Виноградовские чтения I - VIII. Москва, 1978. С. 73.

${ }^{13}$ Городенська К. Г. Структура відіменних дієслів // Городенська К. Г., Кравченко М. В. Словотвірна структура слова (відіменні деривати). Київ, 1981. С. 39-49; Возний Т. М. Словотвір дієслів в українській мові у порівнянні 3 російською та білоруською. Львів, 1981. С. 71-73, 89-93; Пузік А. А. Відприкметникові дієслова у німецькій, англійській та українській мовах : автореф. дис. ... канд. філол. наук : 10.02.17. Донецьк, 2000. С. 5.

14 Грещук В. В. Теоретичні засади основоцентричної дериватології. Відприкметниковий словотвір / В. В. Грещук, Р. О. Бачкур, І. Ф. Джочка, Н. М. Пославська. Нариси з основоцентричної дериватології. Івано-Франківськ : Місто НВ, 2007. С. 149-150.
} 
noted that within the word-formation meaning "to acquire a feature and quality" a number of de-adjectives formed the meaning "to reveal a feature and quality" which for some derivatives is accompanying, whereas for others - the sole meaning.

The semantics of the adjectival topmost verb, its belonging to the definite structural-semantic type, the degree of remoteness from the adjectival stem determine their word-building ability to actually express a certain continuum of derivative meanings and at the same time enhance the potential ability of such verbs to create new derivative units. One of the lexico-semantic groups of adjectives which motivate verbs in the Ukrainian language is the adjectives with the meaning of the features and qualities perceived by our sense organs. The verbs created from these adjectives form two structural-semantic types - inhotatives and causatives which in most cases correlate with the verbs of action and process. Differentional features of these verbs are different: the verbs of action are characterized by dynamism, phaseness, temporal localization, active role of the subject, whereas verbs of process are characterized by dynamism, phaseness, temporal localization, passive role of the subject. This fact, in its turn, has an impact on their derivative ability.

\subsection{Derivative capability of adjectival verbs with word-formation meaning}

\section{"to acquire a feature and quality perceived by the sense organs"}

The study of the inchoative verbs of the Ukrainian language from the point of view of stem-centered derivatology is an important stage of research of the derivational possibilities of derivative verbs in general and of adjectival verbs in particular. Their word-building ability, as mentioned above, is influenced by various factors. Some of them, for example, derivation from the category of qualitative adjectives, activate the derivational process, whereas the others, let us say, belonging to absolutive verbs and the absence of obligatory distributors, on the contrary, slow down or brake. It is only by taking into consideration a complex of these factors we come to the conclusion regarding the filling of the wordformation paradigms of these verbs and to establish the typology of their derivational meanings.

The lexico-semantic group of adjectival inchoative verbs formed with the help of the suffixes -i- and -nu- are divided into four semantic subgroups that are differentiated depending on the sense organ which perceives the feature and quality expressed by the adjective, in particular: 
- sight: bility ${ }^{15}$, bubniavity, hrubity, dribnity, kruhlity, mality, povnity, porozhnity, pustity, rohovity, svizhity, svitlity, spility, tovstity, etc.;

- taste: hirknuty, kvasnity, kyslity, kysnuty, cherstvity, posolonity, etc.;

- hearing: huchnity, tykhnuty, zatykhaty, etc.;

- touch: buchavity, volohnuty, hariachity, mokrity, miaknuty, sokhnuty, teplity, tverdity, tverdnuty, tupity, shershavity, etc.

Initially, the scholars considered inchoative verbs to be the verbs (predicates) of state ${ }^{16}$. Later, I. Vykhovanets interpreted them as specific verbs of the process and as corresponding predicates of process because the predicate of state and quality serve their derivatival base ${ }^{17}$. Therefore, the meaning of such verbs is more precise when qualified as a process.

A typical word-building paradigm of the adjectival inchoative verbs is formed by two zones - substantive and verbal. Substantial zone of the topmost verbs of all four subgroups is represented by devervatives only with the transpositivional word-formation meaning "materialized process". However, due to the fact that basic verbs mostly convey the seme "transformation, the formation of a feature and quality", this wordformation meaning is realized sporadically, inconsistently. The nouns with such semantics were formed only from very few verbs: bubniavinnia, bilinnia, bahrinnia, bliaknennia, hirknennia, zhovtinnia, kysnennia, milinnia, syninnia, tverdinnia, tovstinnia, tuzhavinnia, chervoninnia, etc.

The verbal zone consists of the prefixal verbs with temporal wordformation meanings "the beginning of the acquiring a feature and quality" and "the completion of the acquiring a feature and quality" and with quantitative word-formation meanings "insufficient degree of acquiring of a feature and quality", "sufficient degree of acquiring a feature and quality" and "excessive degree of acquiring a feature and quality".

The means of expression of the temporal word-formation meaning "the beginning of the acquiring a feature and quality" is the prefix za-. According to many linguists, the peculiarity of this formant is the ability to explicate two opposite meanings - the beginning and the end of an action or the establishing of a definite feature, which results in the appearance of such phenomenon as enantiosemy ${ }^{18}$. Many inchoative verbs with the prefix za- (zability, zaholubity, zazhovtity, zazelenity, zasirity, zasynity, zachervonity, zachornity) express these two temporal meanings, for

\footnotetext{
${ }^{15}$ The examples of derivates and the illustrations of their use in context are transliterated from the Ukrainian language.

16 Леута О. І. Семантико-синтаксичні параметри українського дієслова : монографія. Київ : Вид-во Національного педагогічного ун-ту імені М. П. Драгоманова, 2007. С. 61.

${ }^{17}$ Вихованець I. Р. Нариси з функціонального синтаксису. Київ : Наукова думка, 1992. С. 96.

18 Соколова С. О. Префіксальний словотвір дієслів у сучасній українській мові : монографія. Київ : Наукова думка, 2003. С. 215.
} 
example: Zachervonilo nad lisom nebo... (I. Nechui-Levytskyi) i Ochi yoho [Semena] zachervonily do briv (M. Vinhranovskyi).

Prefixes vid- / od-, za-, ob-, u- / v- in the verbal zone of the wordbuilding paradigms of the adjectival inchoative verbs are the indicators of the word-formation meaning "the completion of the acquiring a feature and quality": vidbhrianity, vidbility, vidzhovtity, vidzelenity, vidsynity, vidsyrity, vidvolohnuty, zaderevianity, zakamianity, zatverdity, zatverdnuty, zakholonuty, obmiaknuty, umokrity, etc., for example: Vidsynily pomizh padolystu ostanni prolisky, skapav kholodnyi berezovyi sik (V. Lohvynenko); Vypustyv [Lavrin] porokhivnytsiu, perekhopyv rushnytsiu.., shche kilka raziv zviv i spustyv kurok. Y todi zrozumiv porokh vidsyriv (Iu. Mushketyk).

The depth of the verbal zone of some verbs of this subgroup has several positions. In particular, derivates zasokhnuty, vysokhnuty, vsokhnuty, obsokhnuty, vidsokhnuty, prosokhnuty as components of the word-building paradigm of the verb sokhnuty express temporal finitive meaning "to become dry having lost moisture", for example: Doroha tut pohana, $z$ vyboiamy, shche ne vysokhla vesniana hriaziuka... (U. Samchuk). In addition, each of these perfectives conveys the shade (or shades) of finitive meaning peculiar only to it. For example, zasokhnuty expresses four lexico-semantic variants: 1) "to become unusable losing moisture", for example: Akvarelisty pratsiuiut na paperi doty, doky farby ne zasokhly (L. Bondaruk); 2) "to heal losing moisture": - Niiakoho likaria. Todi sam sebe dokonaiu... Vyduzhaiu, na zhyvomu zasokhne! khrypiv prostudzhenymy hrudmy (M. Stelmakh); 3) "to become stale losing moisture", for example: Zina distala zakruchenu $v$ bantsi tushonku, $a v$ druhii - domashniu kovbasu, banky $z$ polunytsiamy y malosolnymy ohirkamy, yabluka y bilyi khlib, shcho vzhe zasokh za dorohu, chasnyk (V. Lys); 4) "to perish losing moisture", for example: I ne bude Favsta, vmre Mefistofel, $i$ kvitucha yablunia zasokhne, ne prynisshy plodu (U. Samchuk). The last two shades of finitive meaning are also peculiar to the deverbative zsokhnuty, for example: Taraniu vin ziv za obidom, zostavsia odyn khlib, ta y toi zsokh na sukhar (Panas Myrnyi); - Vpered, byky! badyllia zsokhlo, sami valiatsia budiaky, a chereslo, lemish novii... Choho zh vy staly? Hei, byky! (S. Rudanskyi).

The shade "to perish losing moisture" is presented by the verb $v(u)$ sokhnuty, for example: Vydno, riven vody buv kolys vyshchyi, nizh zaraz, i derevo, yak kazhut, zamoklo, vsokhlo vid nadmirnoi volohy (I. Tsiupa). However, besides this shade, deverbative develops one more semantic stratification implemented by the position "to become smaller losing moisture", for example: Pochornila na nim [Severynovi] i sorochka, 
i zdalosia Petrovi, shcho ziviala na poiasi y Nalyvaikova shablia - vona niby vsokhla (M. Vinhranovskyi).

The lexico-semantic variant "to evaporate, to disappear losing moisture" is expressed by deverbatives vysokhnuty, obsokhnuty, prosokhnuty, for example: Richechka, shcho yshla z lisiv, peresokhla, tomu y vysokhly usi stavky na luhakh (M. Stelmakh); Na svizhomu povitri shvydko obsokhly yii instytutski slozy (I. Nechui-Levytskyi). The verb vidsykhaty conveys a semantic shade "to fall off losing moisture", for example: Yoти [Volodtsi] zdavalos, shcho $<\ldots>$ kozhna ruka, shcho odvazhytsia take napysaty, musyt vidsokhnuty, vidletity vid tila $i$ rozsypatysia na porokh (U. Samchuk).

The perfective prysokhnuty depending on the context expresses two word-formation meanings: 1) quantitative, that indicates an insufficient degree of a feature formation, i. e. it means "to become dry a little", for example: Zerno koly prysokhne, peremeletsia - muka, yak sontse (K. Hordiienko); 2) finitive, namely, "the completion of a feature and quality formation" with an additional shade "to stick to something", for example: Tkanyna prysokhla do napukhlykh rubtsiv, zavdaiuchy yomu nesterpnoho boliu (Z. Tulub).

The verbs pidsokhnuty, peresokhnuty convey respectively insufficient and excessive degree of acquiring a feature and quality, for example: Odezha pidsokhla, $i$ my povdiahalysia (V. Shevchuk). Khto $b$ mih podumat, do dna vysokh stavok, nynky, de kolys vyhravaly khvyli, navit zemlia peresokhla i porepalas khymernymy vizerunkamy (V. Ivanyna).

Prefixes z- / s-, o-, po-, pro- give the derivatives the meaning of overall result, eg: otemnity, posvitlity, potemnity, prosvitlity, stemnity, eg: Dmytro yshov poperedu, bo vzhe stemnilo (V. Malyk). Sometimes doublets may be formed: chornity - pochornity, zchornity, tverdity - potverdity, stverdity; teplity - poteplity, steplity: Voda vzhe $v$ richtsi poteplila, prokynulysia raky, - skazav Flor Medvediuk, zakhodiachy do khaty (M. Malynovska).

The derivatives of the verbal zone sporadically show derivational quantative meanings of sufficient, insufficient and excessive degrees of process. In word-building paradigms, inchoative verbs express either one of the named quantitative meanings, in particular, insufficient degree of the process: pryrudity, prysyvity, prytuzhavity, for example: I prysyvila $z$ toho chasu yii [materi] holova (Ie. Hutsalo), or two quantitative meanings: 1) insufficient (pidzhovtity, prychornity) and sufficient (vyzhovtity, $v(y)$ chornity) stages of the process, for example: ...dovkola kozhnoi vuhlyny prychornily doshky $i$ kurily dymkom... (V. Iavorivskyi); 2) sufficient (vybility, nakholonuty) and excessive (perebility, 
perekholonuty) degrees of the process, for example: Vsi $v$ novykh mundyrakh, shcho ne vstyhly shche vybility na doshchakh, sontsi, vsi v skrypuchykh chobotiakh $i$ cherevykakh (I. Chendei); 3) sufficient (vyzelenity, uzelenity) and combined - the initial intensity (or the so-called augmentative verbal category ${ }^{19}$ ), for example rozzelenitys: Pislia doshchu vse vyzelenilo, vykhoroshilo $i$ azh manyt do sebe v hosti (M. Ponedilok); Rozroslys topoli, rozzelenilys (O. Honchar).

\subsection{Derivative ability of the adjectival causative verbs with the word-formation meaning "to endow an object with a feature or quality perceived by the sense organs"}

Causative verbs is one of the three structural-semantic types of the adjectival verbs which is traditionally singled out on the basis of its wordformation meaning - "to endow an object with a feature or quality named by a basic adjective". This type of verbs is quantitatively less numerous than inchoatives, i. e. verbs with word-building semantics "to acquire a feature or quality named by the basic adjectival stem".

Causative verbs with word-formation meaning "to endow an object with a feature or quality perceived by the sense organs" are structured by four semantic subgroups formed depending on the sense organ with which endowing something with a feature or quality is perceived, in particular:

- sight (combines the largest number of verbs motivated by various lexico-semantic groups of base adjectives, primarily with the meaning of color, size, distance, direction, quantity, appearance, etc.): bahrianyty, bilyty, blyzyty, brudnyty, volokhatyty, vuzyty, vialyty, hostryty, hustyty, diriavyty, dribnyty, zhovtyty, zelenyty, kosmatyty, kostrubachyty, koshlatyty, kryvyty, kruhlyty, kudlatyty, pliuhavyty, povnyty, rivniaty, rumianyty, tovstyty, tonchyty, tonshyty, etc.;

- taste: hirchyty, kyslyty, solodyty; oprisnyty тощо, etc.;

- hearing: prytyshyty, styshyty, etc.;

- touch (tactile): volozhyty, hariachyty, derevianyty, kamianyty, mochyty, miakshyty, sushyty; zvohchyty, oteplyty, etc.

The adjectival causative verbs of these semantic subgroups are formed by suffixal and prefixal-suffixal ways. Suffixal verbatives were created mostly with the help of suffix -y-, occasionally -a, for example: brudnyty, volozhyty, hostryty, hustyty, zhovtyty, zelenyty, mochyty, chystyty, rivniaty, etc. For prefixal-suffixal verbs, as opposed to suffixal, a wide set of

\footnotetext{
${ }^{19}$ Соколова С. О. Префіксальний словотвір дієслів у сучасній українській мові : монографія. Київ : Наукова думка, 2003. С. 241.
} 
formants is typical. In the modern Ukrainian language, the prefixal-suffixal way includes the twelve most productive prefixes: vy-, vid-, za-, z- / s-, o- / ob-, pere-, pid-, po-, pry-, pro-, roz-, u- / v- ${ }^{20}$, eight of which are the elements of the confixes (circumfixes) used to create adjectival causative verbs, in particular: vy-... -a, vy-... -y-, z- / s-... -y-, o-... -y-, po-... -y-, pry-... -y-, roz-... -y-, u-... -y-: vydovzhyty / vydovzhuvaty, vyvyshchyty / vyvyshchuvaty, vymilyty / vymiliuvaty, vyporozhnyty / vyporozhniuvaty / vyporozhniaty, vyprostaty / vyprostuvaty, vypriamyty / vypriamliuvaty / vypriamliaty, vidnovyty / vidnovliuvaty / vidnovliaty, zbilshyty / zbilshuvaty, zdovzhyty / zdovzhuvaty, zmenshyty / zmenshuvaty, znyzyty / znyzhuvaty / znyzhaty, zridyty / zridzhuvaty, etc.

\subsubsection{Filling of word-building paradigms of causative suffixal verbs with the derivative meaning "to endow an object with a feature or quality perceived by the sense organs"}

A typical word-building paradigm of the adjectival causative suffixal verbs with the meaning "to endow an object with a feature or quality perceived by the sense organs" consists of three part-of-speech zones substantive, verbal and adjectival. Substantive zone is formed by derivatives with word-formation meanings "materialized action", "a place (a building) for performing an action", "tool of an action", "performer of an action".

The indicator of the transpositional word-formation meaning "materialized action" is usually the suffix -nn- / -enn-, -inn-: bilennia / bilinnia, brudnennia, vialennia, hostrinnia, zolochennia / zolotinnia, kucheriavlennia, pliuhavlennia, rivniannia, solodzhennia, sushennia / sushinnia, sriblennia, chyshchennia, chorninnia, etc., for example: Tut [u dvoryshchi] bulo vkopano zalizni stovpy dlia sushinnia bilyzny (B. Kharchuk).

There is a limited number of causative nouns with the meaning of the materialized action with the suffix -nn- / -enn-, -inn- because many of them are not presented in lexicographic editions, although potentially they are possible, as evidenced by their occasional use in the speech, eg: kosmachennia, koshlannia, koshlatannia, koshlachennia, kudlachennia, chepurinnia / chepurennia, for example: Dukh okhainosti, chepurinnia opanuvav yii [Hafiiku] tsilkom... (M. Kotsiubynskyi).

The derivative meaning "materialized action" in word-buildings paradigms of some causative verbs is also expressed by the suffixes -k-

\footnotetext{
20 Сорочан О. В. Лексико-семантичні групи відприкметникових дієслів (семантичний та функціональний аспекти) : автореф. дис. ... канд. філол. наук : 10.02.01. Київ, 2005. С. 9.
} 
and -n-. The nouns with the word-building formant -k- differ from those analyzed before by a higher degree of verbal feature loss. Neutralization of the verbal feature caused the development of a secondary meaning in the noun sushka - the result (consequence) of an action, for example: Poky dybuliala [baba Vustia] siak-tak, i slukhaty ne khotila, shchob do dochky pereikhaty. - Yaka tam z mene pomich? - vidmakhuvalasia. - A tut ya vam $i$ kartopelky nadbaiu, i sushky na uzvar (L. Brazov), or the object by which the action is carried out, for example:...yakos, koly Tamara stavyla shchoino vymytu tarilku zverkhu na sushku, vona vyslyznula $v$ nei $z$ ruk... (L. Rybenko). In the substantive zone of the topmost causative verb sushyty there is the noun sushnia which is formed with the suffix -n-. The Great Dictionary of Contemporary Ukrainian Language (ed. by V. T. Busel) lists this word with four meanings: 1) the same as sushinnia; 2) dried fruits, berries; sushniak; 3) dry trees, branches; 4) the same as susharka (VTSSUM, 1419). However, its functioning in the speech shows the frequent use of the three object meanings - the product as a result of an action, the tool and the place (building) of an action, which in connection with the possibility of the formation of nouns with the meaning of the materialized action with the help of a more productive word-formation suffix -nn- / -enn-, -inn-, pushed the first of the given meanings to the periphery.

In the substantive zone of the analyzed adjectival causative verbs there are also nouns with the word-formation meaning "a tool of an action". It is explicated by various word-formation formants, the choice of which depends on the semantics and phonetic structure of the verb. The suffix -lis in the role of one of these means. The verbal nouns bilylo, synylo, chornylo, created by means of it, call the means (paint of a certain color or liquid) of an action or a thing that appeared as a result of the performed action.

From the verb rivniaty the derivative for denoting a tool of an action was formed by means of the suffix -lnyk: rivnialnyk; from the verb hostryty - using the suffixes -l- and -lnyk: hostrylo, hostrylnyk.

Finally, from the topmost verb sushyty there are seven nouns with the suffixes -l-, -n-, -lnyk, -ln-, -ar, -ark-, -arn- with instrumental wordbuilding semantics: sushylo, sushnia, sushylnyk, sushylnia, sushar, susharka, susharnia.

All of the above-mentioned formants within the same word-building paradigm, except for the suffix -l-, are polyfunctional since they serve to create nouns with different semantics. In particular, the deverbatives sushylnia, susharka, susharnia, in addition to the word-formation meaning "a device for drying something, removing moisture out of something", 
mean "a place (a building) for drying something" and the nouns sushar, sushylnyk name the performer of an action.

It is the explication of one word-formation meaning in several ways that gives grounds to speak about different depth of the substantive zone in the word-building paradigm of the verb sushyty, for example: the indicators of the meaning "a tool of an action" were 7 suffixes (-1-, -n-, -lnyk, -ln-, -ar, -ark-, -arn-),"a place (a building) of an action” - 5 suffixes (-n-, -ln-, -ark-, -arn-, -Ø-); "a performer of an action" - 2 suffixes (-lnyk, -ar).

The verbal zone combines the derivatives of various word-building modifications - temporal, quantitative and resultative. Temporal modifications are represented by verbs to denote the final stage of an action, created with the help of the prefixes vy-, vid-, do-, za-, z- / s-, na-, o- I ob-, pere-, pro-: vysushyty, vidsvizhyty, vidchystyty, dohostryty, dosushyty, dochystyty, zabrudnyty, zavolozhyty, zavialyty, zahostryty, zahustyty, zakryvyty, zakruhlyty, zachystyty, zblyzyty, zsushyty, zchystyty, nablyzyty, osushyty, okholodyty, perekryvyty, prodiriavyty and others. Such a number of formants is an indicator, firstly, of variety of word-formation means for the expression of finitive semantics; secondly, of the corresponding depth of semantic positions within a single word-formation paradigm; and thirdly, of the ability to express additional semantic shades. For example, derivatives zarivniaty, obrivniaty, pidrivniaty, zrivniaty, vyrivniaty are formed from the verb rivniaty.

All of them, except for the finitive meaning, convey additional semantic shade - indicate the way of performing an action. In particular, the deverbative zarivniaty means "to make flat, to fill up the pits" (VTSSUM, 418). The same word-formation semantics are duplicated by deverbatives rozrivniaty and zrivniaty. However, each of the named verbs conveys one more lexico-semantic variant: rozrivniaty - "to make a smooth, straight; to smooth out, to straighten out" (VTSSUM, 1261); zrivniaty - "to put in a row (or rows) in a straight line" (VTSSUM, 479). The deverbative obrivniaty explicates the final stage of an action achieved by "smoothing out the edges, surfaces of something" (VTSSUM, 816). Among all the perfectives derived from the causative rivniaty the largest number of lexico-semantic variants is expressed by the verb vyrivniaty. Duplicating all of the above-mentioned lexico-semantic variants, it conveys two other shades - "to make straight, to straighten out something curved" and "to make equal vertically or horizontally".

Quantitative modifications of causative verbs are represented by three subgroups. The first is formed by perfectives to indicate the repeated performing of an action. They are created by the prefix pere-: perebilyty, perebiluvaty, perevialyty, perehostryty, perezolotyty, peremochyty, 
peresynyty, peresushyty, perechystyty, for example: A potim by toi chornovyk mozhna bulo perebilyty, perepysaty nachysto, unyknuvshy poperednikh pomylok i ohrikhiv (M. Nechai).

The second subgroup includes deverbatives indicating the degree of endowing a predicative feature: insufficient, sufficient and excessive. The verbs with insufficient degree of endowing a feature and quality are formed by prefixes pid-, pry-, occasionally nad-: pidbilyty, pidvolozhyty, pidvialyty, pidhostryty, pidhustyty, pidkyslyty, pidkucheriavyty, pidmochyty, pidrumianyty, pidsvizhyty, pidsynyty, pidsolodyty, pidsushyty, pidchervonyty, pidchystyty, for example:...naviduietsia iz susidnoho sela donka Vasylyna ne tak, aby nahotuvaty ta nachepuryty, yak aby vyklasty $z$ torby smachnykh naidkiv hotovykh, batkovi khatu prybraty, pidbilyty, pozamazuvaty... (I. Chendei).

The prefixes vy-, occasionally pro-, vid-, na- express achievement of sufficient intensity of a predicative feature: vybilyty, vybrudnyty, vyvialyty, vyhostryty, vyzhovtyty, vyzelenyty, vyzolotyty, vykryvyty, vykruhlyty, vymochyty, vyrivniaty, vysynyty, vysvizhyty, vysriblyty, for example: Trudyvsia ya chymalo, skilky nanosyv hychky - nevidomo. Choboty promokly, svytynku vsiu vybrudnyv u mokru zemliu (I. Senchenko). Perfectives with the prefix na- express an additional shade of cumulativeness on condition that there is a large amount of something, for example: Asfalt stelyvsia, yak suvii polotna, shcho yoho nabilyla za vikvystachylo b prostelyty do Krasnohrada (M. Ishchenko).

Excessive degree of the performed action is expressed by prefixes pere-, roz- : perebilyty, perehirchyty, perehostryty, perehustyty, perezhovtyty, perekyslyty, peremochyty, peresynyty, peresolodyty, peresushyty, rozrumianyty, for example: Hlynu krashche ne dosushyty, nizh peresushyty (M. Dubovyk).

The prefixes pere- and po-, explicating the direction of an action to a large number of objects, create deverbatives with distributive meaning which forms the third subgroup of quantitative modifications: perebilyty, perebiluvaty, perebrudnyty, perevialyty, perehostryty, perezhovtyty, perezolotyty, peresynyty, peresushyty, perekholodyty, perechystyty, posushyty, potupyty, for example: Na kozhnomu kryli roslo po velykii hrushi, starii, drimuchii, yaki shchovesny tsvily po-molodechomu husto y pakhucho, a pid osin obsypaly dodolu takyi hrushkopad tsukrystykh dychok, shcho y ne vyzbyraiesh yikh usi, y ne peresushysh (Ie. Hutsalo).

The perfectives rozmochyty and vidmochyty, which are created by means of the prefixes roz- and vid-, somewhat change the semantics of the basic verb - the performing of the action determined by them led to the appearance of a new quality in an object, namely: rozmochyty - "to make it 
soft, to cause swelling" (VTSSUM, 1253), for example: Kozaky nahortaiut u kazany pukhkoho snihu, nesut do vohnyshcha.., aby zihrity okropom zadubile tilo ta rozmochyty sukhari (M. Syrotiuk); vidmochyty conveys three meanings: "to soften something dry", for example: Susheni hryby vidmochyty $i$ vidvaryty, zmishaty $z$ buriakom (H. Kozholianko); "to separate two things attached", for example: Chystenka babusia, bidkaiuchys $i$ spleskuiuchy rukamy, vidmochyla bynty, $i$ Hryhorii, ztsipyvshy zuby, poprosyv rvonuty yikh zrazu, a ne tiahty razom z dusheiu (V. Miniailo); "to help with easy, quick and good cleaning from dirt, rust", for example: Vona [rushnytsia] sylno porzhavila... Ya yii vidmochyv u hasi, ochystyv vid irzhi, zmazav i zamok pochav pratsiuvaty (L. Nevidomskyi).

The adjectival zone of the typical word-formation paradigm of suffixal causative verbs is represented by derivatives with the suffix -lnwhich express the word-formation meanings "intended for performing an action named by the basic verb" and "connected with an action named by the basic verb": bilylnyi, hostrylnyi, mochylnyi, synylnyi, solodylnyi, sriblylnyi, sushylnyi, etc., for example: Susharky z nerukhomym sharom zerna - tse shakhta z pokhylym abo horyzontalnym dnyshchem abo kolonka iz sytovymy stinkamy, $u$ yakykh sushylnyi ahent prokhodyt cherez shar zerna $v$ riznykh napriamkakh (O. Datsyshyn) i $N a$ druhomu etapi modernizatsii zminiuvalas sushylna chastyna mashyny, vstanovliuvavsia klynoreminnyi pryvid dlia 10 sushylnykh hrup (V. Studinskyi).

\subsubsection{Word-formation potential}

of causative prefixal-suffixal verbs with derivative meaning

"to endow an object with a feature or quality perceived by the sense organs"

A typical word-formation paradigm of prefixal-suffixal causative verbs with a derivative meaning "to endow an object with a feature or quality perceived by the sense organs" has three zones - substantive, verbal and adjectival. The substantive zone unites nouns with three semantic positions: "materialized action", "a tool of an action" and "a performer of an action". The first of these meanings - "materialized action" - is expressed by the suffix -nn- / -enn-, -inn-, which primarily transfers the verbal stem into a noun space, i. e. performs a transpositional function. Such verbal nouns do not only preserve the semantics of the basic verb but also often inherit its grammatical category of aspect ${ }^{21}$. This fact is evidenced by the tendency to create nouns from both components of the

\footnotetext{
21 Пілецький В. Назви процесових понять у науково-технічній термінології. Актуальні проблеми українського словотвору. Івано-Франківськ : Плай, 2002. С. 462.
} 
correlative aspect pair (perfect verb and imperfect verb), cf.: vydovzhennia / vydovzhuvannia, vypovnennia / vypovniuvannia, vyporozhnennia / vyporozhniuvannia / vyporozhniannia, vidnovlennia / vidnovliuvannia, zbilshennia / zbilshuvannia, zdovzhennia / zdovzhuvannia, zridzhennia / zridzhuvannia, obnovlennia / obnovliuvannia / obnovliannia, etc.

Some substantives with the suffix -nn- / -enn- correlated with perfect verbs in addition to the meaning "materialized action" acquired secondary word-formation meanings: 1) the result, the consequence of an action: vydovzhennia, vidnovlennia, obnovlennia, onovlennia, polehshennia, polipshennia, ponovlennia, uskladnennia, etc., for example: Yakshcho zminiuvaty znachennia syly, to zminiuvatymetsia $i$ dovzhyna pruzhyny, tobto yii vydovzhennia (M. Holovko); 2) a person or people: dopovnennia, popovnennia, for example: Perekydaiuchysia zhartamy, pasazhyrske popovnennia zruchno vmoshchuietsia na svoikh klunkakh (Iu. Koval); 3) an object: popovnennia, for example: - Ahov, Vasylyno, pryimai popovnennia! Did Yakym tprukaie na vhodovanykh konei, krekchuchy zsadzhuie z voza vazhkyi bidon (Iu. Koval); 4) a place (a location) of an action, for example: znyzhennia, pidvyshchennia, ponyzhennia, for example: Khudorliavyi $i$ pidtiahnutyi tysiatskyi Mykhailo Rodko rozghlianuvsia.., a todi vpevneno stupyv na pidvyshchennia, poklonyvsia mytropolytu i kniazevi (O. Lupii). These secondary meanings of the abovementioned nouns give grounds to consider them transpositional-mutational derivatives.

The use of nouns with the suffix -nn- / -enn- formed from causative prefixal-suffixal verbs is functionally limited. They are used mainly in the scientific-technical and financial-economic spheres to denote a certain action. Along with the nomination of an action, accompanied by changes of the object, it is necessary to determine the quantitative indicators (measurements) of this action. Therefore, some derivatives with the formant -enn- also developed an ability to explicate the magnitude "the quantity of an action" 22 that quantitatively characterizes this action. This magnitude is expressed by adding the words with quantitative semantics such as coefficient, magnitude, number, gradient, index, level, angle, square, to the created substantives: vydovzhennia and pokaznyk vydovzhennia, vidnovlennia and koefitsiient (pokaznyk) vidnovlennia, vyporozhnennia and koefitsiient vyporozhnennia, onovlennia and koefitsiient onovlennia, etc., for example: Koefitsiient onovlennia osnovnykh vyrobnychykh fondiv mav tendentsiiu do stiikoho znyzhennia (B. Panasiuk).

\footnotetext{
22 Пілецький В. Назви процесових понять у науково-технічній термінології. Актуальні проблеми украӥнського словотвору. Івано-Франківськ : Плай, 2002. С. 461.
} 
Another way of expressing the meaning of a materialized action in the substantive zone of word-building paradigms of some causative prefixalsuffixal verbs is the zero suffix, for example: vidnova, obnova, onova, perepovnia, polehsha, ponova, for example: Nesvyzkyi bahato hovoryv nam pro vidnovu derzhavy sviatoho Volodymyra, - zakinchyv Sudyslav, - $i$ my zrozumily, shcho taka derzhava ne postane bez voli-svobody narodu (Iulian Opilskyi). It is significant that verbal nouns with zero suffix, in contrast to the derivatives with suffix -nn- formed from verbs of an imperfect aspect, have a weakened procedurality of the meaning expressed by them. This predetermines their ability to express resultative meaning to a greater extent ${ }^{23}$, which pushes the primary word-formation meaning "materialized action". In particular, the derivate obnova means "new, newly bought, sewed, presented item (about clothes, shoes)" (SUM V, 546), for example: ...vony [cherevychky] buly taki harni, taki novenki, tak pryiemno pakhly obnovoiu, shcho, zdavalosia, onovyly vsiu yikhniu kvartyru (B. Kharchuk).

Another group of derivatives systematically represented in the subjective zone of causative verbs are the derivatives with the suffix -ach / -yach. This word-building formant is polyfunctional. It expresses simultaneously the word-building meanings "a performer of an action" and "a tool of an action" in word-building paradigms of many verbs. Additionally, linguists consider the first word-building meaning to be the primary, whereas the secondary one is formed on the basis of the primary and causes the phenomenon of suffixal homonymy.

The use of the suffix -ach / -yach for the formation of nouns with the word-building meaning "a tool of an action" is quite productive. From the point of view of many linguists, this word-formation means is marked by the highest degree of semantic-syntactic instrumental function realization ${ }^{24}$. It is also productive in the formation of nouns from prefixal-suffixal causative verbs. These nouns name: 1) devices: vyprostuvach, vypriamliach, zridzhuvach, oprisniuvach, rozpriamliuvavach, for example: Vypriamliach - tse elektrotekhnichnyi elektronnyi prystrii, pryznachenyi dlia peretvorennia odno- abo bahatofaznoi zminnoi napruhy u postiinu $z$ potribnymy znachenniamy velychyny vykhidnoi napruhy, strumu ta koefitsiienta pulsatsii (Ie. Chemes); 2) materials (substances) intended to perform actions in a particular production process, such as: dopovniuvach, zapovniuvach, napovniuvach, onovliuvach, otepliuvach, rozridzhuvach, polipshuvach, ponovliuvach, pryskoriuvach, polehshuvach, uskladniuvach,

\footnotetext{
23 Городенська Г. К. Проблема виділення словотвірних категорій (на матеріалі іменника). Мовознавство. 1994. № 6. С. 26; Олексенко В. П. Словотвірні категорії іменника : монографія. Херсон : Айлант, 2005. С. 213.

${ }^{24}$ Олексенко В. П. Словотвірні категорії іменника : монографія. Херсон : Айлант, 2005. С. 82. 
utepliuvach, ushchilniuvach, for example: Inkoly, osoblyvo vzhe v 1900-kh rokakh, Vasylkivskyi podibnoho vrazhennia dosiahav, nakladaiuchy mazky duzhe shchilno y dodaiuchy v rozridzhuvach lak (I. Ohiievska).

The verbal zone is comprised of the verbs created exclusively by postfix -sia. This word-building formant gives the topmost causative prefixal-suffixal verbs the word-formation meaning "to become as defined by the adjectival stem", which led to the shift of postfixal verbs to the structural-semantic type of inchoatives. Such changes in the word-building semantics are presented by almost all deverbatives with the postfix -sia, cf.: vydovzhytysia / vydovzhuvatysia, vyvyshchytysia / vyvyshchuvatysia, vyokremytysia / vyokremliuvatysia, vyporozhnytysia / vyporozhniuvatysia / vyporozhniatysia, vidnovytysia / vidnovliuvatysia / vidnovliatysia, dopovnytysia / dopovniuvatysia / dopovniatysia, zapovnytysia / zapovniuvatysia / zapovniatysia, zbilshytysia / zbilshuvatysia, etc.

The adjectival zone is filled with adjectives with the suffix -ln-, attached to the stem of verbs of an imperfect aspect. They express the two word-formation meanings: 1) "intended to perform an action named by the basic verb": dopovniuvalnyi, zapovniuvalnyi, zbilshuvalnyi, zmenshuvalnyi, znyzhuvalnyi, zridzhuvalnyi, oprisniuvalnyi, pidvyshchuvalnyi, polehshuvalnyi, ponyzhuvalnyi, ushchilniuvalnyi, etc., for example: Uposushlyvykh pryberezhnykh raionakh pratsiuiut oprisniuvalni ustanovky (H. Dovhan); 2) "connected with the action named by the basic verb": vidnovliuvalnyi, zdovzhuvalnyi, popovniuvalnyi, spovilniuvalnyi, ukrupniuvalny, for example: Sohodni $19 \%$ vyrobnytstva svitovoi enerhii zabezpechuiut dzherela vidnovliuvalnoi enerhii... (O. Alymov). Adjectives vyprostuvalnyi, napovniuvalnyi, onovliuvalnyi, otepliuvalnyi, ponovliuvalnyi, pryskoriuvalnyi, pryshvydshuvalnyi, rozridzhuvalnyi, utepliuvalnyi explicate both of these meanings: Provedennia kompleksnykh zakhodiv iz resurso- ta enerhozberezhennia dast mozhlyvist ... stvoryty umovy dlia vykorystannia etanolu ne tilky $v$ kharchovii promyslovosti, a y $u$ inshykh haluziakh yak ponovliuvalnoi orhanichnoi syrovyny ta biopalyva (R. Kyrylenko) and Na terytorii pidpryiemstva hotelnoho hospodarstva dotsilno zdiisniuvaty remontni ta ponovliuvalni roboty na oblashtovanykh dytiachykh ta sportyvnykh maidanchykakh, $u$ parkakh $i$ skverakh vidpochynku, na pliazhakh toshcho (M. Boiko).

The derived adjectives strengthen the "verbal meaning of an action towards the constant feature of an object" 25 . It is this specificity of the adjective that determines its ability to replenish the composition of the terminological units. This process has become noticeably activated in the

\footnotetext{
${ }^{25}$ Вихованець І. Р. Частини мови в семантико-граматичному аспекті. Київ : Наукова думка, 1988. C. 17.
} 
modern term-formation, which causes the functioning of some verbal adjectives as terms that are either partially represented by lexicographic sources or are not featured there at all.

\section{CONCLUSIONS}

Adjectival verbs of the Ukrainian language have a complex hierarchical structure because their word-formation meanings, formed by the definite lexico-semantic group of basic adjectives and word-formation means, are subordinated to the broader classificational unit - structuralsemantic type. On the one hand, these verbs belong to the structuralsemantic types of inchoatives, essives or causatives and it determines their unification in lexico-semantic groups and, on the other hand, specifies the conditionality of their word-formation potential by additional factors typical only of a particular structural-semantic type. In particular, the division of the adjectival verbs into inchoatives, essives or causatives is to a certain extent related to their correlation in the sentence with the predicates of the process, state and action, which valency-derivational capacity is different leading to the different filling of typical wordformation paradigms.

Adjectives with the semantics of a feature or quality perceived by the sense organs motivate mostly the verbs of two structural types - causative and inchoative. Causative verbs, which often indicate a concrete physical action, depending on the word-formation means, which transfers the adjectival stem to the verbal stem, form a group of suffixal and prefixalsuffixal units. A typical word-building paradigm of causative suffixal verbs is represented by the derivatives of the substantive, verbal and adjectival zones. The content of the substantive zone is the most extensive since each of its word-formation meanings, in particular, "materialized action", "a place (a location) for performing an action", "a tool of an action", "a performer of an action", "a result (consequence) of an action", is implemented through several word-building formants. The verbal zone is filled with prefixal verbs with temporal and quantitative word-formation meanings. Temporatives are represented by numerous verbs to indicate the final stage of an action, which testifies to the depth of this semantic position; quantitives - by verbs with the semantics of a repeated performance of an action, as well as various degrees (insufficient, sufficient and excessive) of endowing a predicative feature. The adjectival zone of causative suffixal verbs consists of adjectives formed by suffix -lnwith word-formation meanings "intended for performing of an action named by the basic verb" and "connected with an action named by the basic verb". 
A typical word-building paradigm of the prefixal-suffixal causative verbs also consists of three zones. The prefixal-suffixal paradigm differs from the suffixal paradigm by a smaller number of semantic positions and word-building formants for their explication. The specificity of the structure of word-building paradigms with topmost inchoative verbs which mostly name a process is that, firstly, they do not have an adjectival zone; secondly, the substantive zone is filled with derivatives with the meaning of the materialized process, which gives grounds to consider it to be monotypic; thirdly, the verbal zone is represented predominantly by prefixal verbs with temporal word-formation meanings "the beginning of the acquiring a feature and quality", "the completion of the acquiring a feature and quality" and quantitative meanings "insufficient degree of acquiring a feature and quality", "sufficient degree of acquiring a feature and quality", "excessive degree of acquiring a feature and quality".

\section{SUMMARY}

The proposed article establishes the parameters of typical wordbuilding paradigms of the Ukrainian verbs motivated by adjectives, which express features of objects perceived by the sense organs. These typical word-building paradigms serve as the indicators of the derivational potential of the basic adjectival verbs in the modern Ukrainian language. As known, they belong to the two structuralsemantic types - causatives and inchoatives - thus determining their functional-categorical status in the definite syntagmatic environment. Correlation of verbs-causatives with predicates of action and of verbsinchoatives with the predicates of process influences their word-formation ability depending on their differential features. Verbscausatives are characterized by basic differential features of dynamism, phaseness, temporal localization and active role of the subject, whereas verbs-inchoatives with the predicates of the process are characterized by dynamism, phaseness, temporal localization and passive role of the subject. Word-building paradigms are structured by morphological zones which contain deverbatives of different part-of-speech status. The author determines a continuum of semantic positions realized by topmost verbs with the help of certain word-formation means within each zone and traces the ability of derivative units to develop additional semantic shades. 


\section{REFERENCES}

1. Адамець Н. В. Словотвірна парадигматика дієслів руху в сучасній українській мові : автореф. дис. ... канд. філол. наук : 10.02.01. Івано-Франківськ, 2016. 20 с.

2. Василевич Г.Я. Типи словотвірних значень девербативівіменників у віддієслівних гніздах зі значенням мислення. Дослідження зі словотвору та лексикологї. Київ : Вища школа, 1985. C. 25-30.

3. Вихованець I. Р. Частини мови в семантико-граматичному аспекті. Київ : Наукова думка, 1988. 255 с.

4. Вихованець I. Р. Нариси з функціонального синтаксису. Київ : Наукова думка, 1992. 222 с.

5. Возний Т. М. Словотвір дієслів в українській мові у порівнянні з російською та білоруською. Львів : Вища школа, 1981. 187 с.

6. Голянич М. И. Словообразовательные поля корней со значением говорения в современном украинском языке : автореф. дисс. ... канд. филол. наук : 10.02.02. Киев, 1979. 24 с.

7. Городенська Г. К. Проблема виділення словотвірних категорій (на матеріалі іменника). Мовознавство. 1994. № 6. С. 25-28.

8. Городенська К. Г. Структура відіменних дієслів // Городенська К. Г., Кравченко М. В. Словотвірна структура слова (відіменні деривати). Київ, 1981. С. 20-108.

9. Грещук В. Український відприкметниковий словотвір. ІваноФранківськ : Плай, 1995. 208 с.

10. Грещук В. Теоретичні засади основоцентричної дериватології. Відприкметниковий словотвір // Грещук В. В., Бачкур Р. О. та ін. Нариси $з$ основоцентричної дериватології. Івано-Франківськ, 2007. C. 6-38, 107-153.

11. Джочка I. Ф. Віддієслівний словотвір // В. В. Грещук, Р. О. Бачкур, І. Ф. Джочка, Н. М. Пославська. Нариси 3 осново центричної дериватології. Івано-Франківськ : Місто НВ, 2007. С. 154-259.

12. Земская Е. А. О парадигматических отношениях в словообразовании. Русский язык: Вопросы его истории и современного состояния. Виноградовские чтения I-VIII. Москва, 1978. C. 63-77.

13. Ковалик I. I. Словотвір іменників у сербо-лужицьких мовах. Львів, 1964.

14. Кушлик О. П. Словотвірна парадигматика похідних дієслів в українській мові : монографія. Дрогобич : Коло, 2015. 384 с. 
15. Лесюк Н. П. Словообразовательные гнёзда корней со значением движения в современном украинском языке : автореф. дисс. ... канд. филол. наук : 10.02.02. Киев, 1982. 25 с.

16. Лесюк М. П. Дослідження словотвору на рівні словотвірних гнізд. Вісник Прикарпатського нач. ун-ту ім. В. Стефаника. Філологія. Івано-Франківськ, Вид-во Прикарпатського національного університету, 2007. Вип. 15-18. С. 212-216.

17. Леута О. I. Семантико-синтаксичні параметри українського дієслова : монографія. Киъв : Вид-во Національного педагогічного університету імені М. П. Драгоманова, 2007. 404 с.

18. Олексенко В. П. Словотвірні категорії іменника : монографія. Херсон : Айлант, 2005. 336 с.

19. Пілецький В. Назви процесових понять у науково-технічній термінології. Актуальні проблеми украӥнського словотвору. ІваноФранківськ : Плай, 2002. С. 459-469.

20. Пославська Н. М. Віддієслівний словотвір // В.В.Грещук, Р. О. Бачкур, І. Ф. Джочка, Н. М. Пославська. Нариси з основоцентричної дериватології. Івано-Франківськ : Місто НВ, 2007. С. 154-179, 259-324.

21. Пузік А. А. Відприкметникові дієслова у німецькій, англійській та українській мовах : автореф. дис. ... канд. філол. наук : 10.02.17. Донецьк, 2000. 21 с.

22. Сегін Л. В. Структурно-семантична типологія словотвірних парадигм дієслів динамічної просторової локалізованості в українській та польській мовах: автореф. дис. ... канд. філол. наук : 10.02.17. Донецьк, 2003. 20 с.

23. Соколов О. М. До проблеми зв'язку словотвірної мотивації з валентністю мовних одиниць. Проблеми сучасного життя мови. Київ : Наукова думка, 1977. С. 3-10.

24. Соколова С. О. Префіксальний словотвір дієслів у сучасній українській мові : монографія. К. : Наукова думка, 2003. 283 с.

25. Сорочан О. В. Лексико-семантичні групи відприкметникових дієслів (семантичний та функціональний аспекти) : автореф. дис. ... канд. філол. наук : 10.02.01. Київ, 2005. 18 с.

26. Тишківська Н. Я. Семантико-словотвірні зв'язки між компонентами словотвірного гнізда 3 вершиною кохати в сучасній українській мові. Українське мовознавство. 1985. Вип. 13. С. 38-45.

27. Уфимцева А. А. Лексическое значение. Москва : Наука, 1986. $240 \mathrm{c}$. 
28. Grzegorczykova R., Puzynina J. Problemy ogólne słowotwórstwa // Gramatyka współczesnego języka polskiego. Warszawa : PWN, 1998. Vol. 2 : Morfologia. S. 361-388.

\section{DICTIONARIES}

VTSSUM - Velykyi tlumachnyi slovnyk suchasnoi ukrainskoi movy / [uklad. i holov. red. V. T. Busel]. Kyiv; Irpin : Perun, 2009.1736 s.

SUM - Slovnyk ukrainskoi movy : V 11-ty t. Kyiv : Naukova dumka, 1970-1980.

\section{Information about the author:} Kushlyk O. P., Doctor of Philology,

Professor at the Ukrainian Language Department, Ivan Franko Drohobych State Pedagogical University 16/3, A. Sheptytskyj str., Drogobich, 82104, Ukraine 